Yuko Tazuke · Robert A. Drongowski - Imad Btaiche

Arnold G. Coran · Daniel H. Teitelbaum

\title{
Effects of lipid administration on liver apoptotic signals in a mouse model of total parenteral nutrition (TPN)
}

Published online: 18 March 2004

(C) Springer-Verlag 2004

\begin{abstract}
Lipids are an important component of total parenteral nutrition (TPN), contributing the largest caloric load per volume of solution and providing essential fatty acids necessary for survival. However, lipids are known to be causative factors in oxidative stress, which are expressed via the Bcl-2 family of proteins and/or Fas-mediated apoptosis in several tissues. Interestingly, we have recently observed an increase in hepatocyte apoptosis with administration of TPN. To address the mechanism of this apoptosis, we investigated the effects of parenteral lipid administration on apoptotic signaling in a mouse model. C57BL/6J male mice received physiologic saline and standard chow (control) or standard TPN solution with (TPN $+\mathrm{L})$ or without lipid (TPN-L) emulsion. After 7 days of infusion, apoptosis increased in the TPN $+\mathrm{L}$ at a significantly higher rate compared with control and TPN-L groups $(p<0.05)$. Both TPN, with and without lipids, suppressed the pro-apoptotic signals Bid and Bcl-xs $(p<0.05)$. In contrast, TPN with lipid increased the expression of Fas and both the pro-apoptotic factor Bad and the anti-apoptotic factor $\operatorname{Bcl-xl}(p<0.05)$. These changes may contribute to TPN-induced hepatocyte injury (apoptosis) or suppress the ability of liver hepatocytes to regenerate.
\end{abstract}

Keywords Total parenteral nutrition (TPN) · Lipid · Apoptosis $\cdot$ Hepatocyte

Y. Tazuke $\cdot$ R. A. Drongowski · A. G. Coran

D. H. Teitelbaum ( $\square)$

Section of Pediatric Surgery, Department of Surgery,

University of Michigan Medical School,

F3970 Mott Children's Hospital, Ann Arbor,

MI 48109-0245, USA

E-mail: dttlbm@med.umich.edu

Fax: + 1-734-936-9784

I. Btaiche

Pharmacy Department, University of Michigan Medical School, Mott Children's Hospital, Ann Arbor, MI, USA

\section{Introduction}

Lipids are an important component of total parenteral nutrition (TPN). Fat emulsions are particularly valuable in pediatric TPN because they provide an isotonic solution rich in calories. Clinically, fat-free TPN may rapidly lead to essential fatty acid deficiency. [1, 2, 3, 4, 5]. Therefore, parenteral administration of essential phospholipids, via lipid emulsions, is critical [6]. Additionally, the inclusion of lipid emulsions with TPN prevents hepatic steatosis [7, 8, 9] and is useful for hepatic regeneration after partial hepatectomy [10].

Despite the need for lipids, lipid administration may have several potential problems. Lipid uptake is known to stimulate macrophages and thereby plays a role in lung tissue inflammation seen in response to long-term lipid-based TPN in pigs [11]. Additionally, TPN-associated cholestasis has been reported to increase significantly in patients administered lipids as part of their TPN regimen [7]. Additionally, lipid emulsions are known to be causative factors in mitochondrial oxidative stress, which is expressed via the Bcl-2 family of proteins and/or Fas-mediated apoptosis in liver tissues [12, 13, 14, 15, 16]. A major intracellular signaling pathway for apoptosis is mediated by the Bcl-2 family of proteins. Members of this family can either function to prevent apoptosis (Bcl2, Bcl-xl, Bcl-w) or support intracellular apoptotic signaling (Bax, Bak, Bid, Bad, Bcl-xs).

We have recently observed an increase in hepatocyte apoptosis with TPN administration using a mouse model, similar to the increase in intestinal epithelial cell apoptosis and resulting in villus atrophy [17]. However, the mechanism responsible for this increase in hepatocyte apoptosis is not clear. Because lipid administration has been associated with the development of TPNassociated cholestasis [18], we hypothesized that the observed increase in hepatocyte apoptosis may be due in part to the inclusion of lipids. To address the mechanism of this TPN-associated apoptosis seen in liver tissue, we investigated the expression of various pro-apoptotic and 
anti-apoptotic factors. We hypothesized that the hepatocyte apoptosis observed with TPN administration would be associated with an increase in pro-apoptotic signals and a concomitant decrease in anti-apoptotic signals, with the effect being greater in the TPN $+\mathrm{L}$ group.

\section{Materials and methods}

\section{TPN model}

C57BL/6J male, 10-12-week-old, specific pathogen-free mice (Jackson Laboratories, Bar Harbor, ME) weighing 23-25 g were housed in metabolic cages and underwent an acclimatization period of 1 week. They were fed standard chow and had access to tap water ad libitum. The mice were maintained in a 12:12-hr day/night rhythm at a constant temperature of $23^{\circ} \mathrm{C}$ and a relative humidity of $40-60 \%$. They were anesthetized with $50 \mathrm{mg} / \mathrm{kg}$ of sodium pentobarbital intraperitoneally. A silastic rubber catheter $(0.012$ inch i.d. $\times$ 0.025 inch o.d., Konigsberg Instruments, Pasadena, CA) was inserted into the superior vena cava through the left jugular vein, tunneled subcutaneously, and brought out through the skin of the midscapular region with a swivel spring. This set-up allowed the mice freedom of movement in their metabolic cages (Metamount System, Instech, Plymouth Meeting, MA). Catheterized mice were connected to an infusion pump (AIM pain provider pump, donated by Abbott Laboratories, Abbott Park, IL), and saline (dextrose 5\% in $0.45 \%$ normal saline with $20 \mathrm{mEq} \mathrm{KCl} / \mathrm{L}$ ) was infused at an initial rate of $9.6 \mathrm{ml} /$ day. After $24 \mathrm{~h}$ the animals were randomized into the following three groups: The control group received the same intravenous physiologic saline solution at $7 \mathrm{ml} / 24 \mathrm{~h}$, in addition to standard laboratory mouse chow and water ad libitum. The TPN-treated groups received either standard TPN solution with $(\mathrm{TPN}+\mathrm{L})$ or without lipid (TPN-L) emulsion intravenously at $7 \mathrm{ml} / 24 \mathrm{~h}$ with no enteral nutrition. The TPN solution contained a balanced mixture of amino acids and dextrose in addition to electrolytes, trace elements, and vitamins. Caloric delivery was based on caloric intake measurements from previous investigators so that caloric and protein delivery was essentially the same for the three groups. Caloric delivery was compensated by an increased delivery of dextrose. After 7 days of total continuous infusion, blood was collected for liver biochemistry tests, and the mice were sacrificed using $\mathrm{CO}_{2}$. Whole liver samples were harvested and sliced into approximately equal quantities and stored at $-70^{\circ} \mathrm{C}$ until examination.

\section{Apoptosis detection}

Hepatocyte apoptosis was detected by the TUNEL staining kit according to the manufacturer's instructions (in situ cell death detection (POD) kit, Roche Diagnostic, Penzberg, Germany). Apoptosis was expressed as the number of positive cells per 200 hepatocytes examined using a microscope.

Liver biochemical assays

Aspartate aminotransferase (AST), alanine aminotransferase (ALT), alkaline phosphatase (alk phos), cholesterol, glucose and gamma glutamyltransferase (G-GGT) were measured by standard assay techniques (Ektachem 750 system, Johnson and Johnson, New Brunswick, NJ) using mouse serum, stored at $-70^{\circ} \mathrm{C}$ until assay.

mRNA expression

mRNA expression of apoptotic factors was measured by semiquantitative reverse transcriptase polymerase chain reaction
(RT-PCR) techniques. Liver total cellular RNA was obtained using TRIzol Reagent (Gibco BRL, Gaithersburg, MD), according to the manufacturer's instructions, and purified RNA samples were stored at $-70^{\circ} \mathrm{C}$ until examination. Next, $5 \mu \mathrm{g}$ of RNA was added to an RT mixture (total volume $28 \mu \mathrm{L}$ ) of $5 \mu \mathrm{L}$ of $10 \times$ PCR buffer II (Perkin-Elmer Roche, Foster City, CA), $10 \mu \mathrm{L}$ of $25 \mathrm{mM} \mathrm{MgCl} 2$ (Perkin-Elmer Roche, Foster City, CA), $5 \mu \mathrm{L}$ of $10 \mathrm{mM}$ dNTPs (Roche Molecular Biochemicals, Indianapolis, IN), $1.5 \mu \mathrm{L}$ of $40 \mathrm{U}$ RNAase inhibitor (Roche Molecular Biochemical, Indianapolis, IN), $4 \mu \mathrm{L}$ of $50 \mu \mathrm{M}$ Oligo (dT)12-18 (Gibco BRL, Gaithersburg, MD), and $2.5 \mu \mathrm{L}$ of $200 \mathrm{U} / \mu \mathrm{L}$ M-MLV reverse transcriptase (Gibco BRL, Gaithersburg, MD). The sample mixtures were incubated at $40^{\circ} \mathrm{C}$ for $70 \mathrm{~min}$ and at $95^{\circ} \mathrm{C}$ for $3 \mathrm{~min}$ and stored at $4^{\circ} \mathrm{C}$ until the polymerase chain reaction $\{\mathrm{PCR}$ ). The PCR mixture contained 1 $\mu \mathrm{L}$ each of $5 \mu \mathrm{M}$ primer pair [17], $0.8 \mu \mathrm{L}$ of $10 \times$ PCR buffer, $0.2 \mu \mathrm{L}$ of $25 \mathrm{mM} \mathrm{MgCl} 2$, and $0.1 \mu \mathrm{L}$ of $5 \mathrm{IU} / \mu \mathrm{L}$ Ampli Taq DNA polymerase (Perkin-Elmer Roche, Foster City, CA), with sufficient DEPC-treated water to bring the mixture to a total volume of $6 \mu \mathrm{L}$. Primer pairs were designed with an optimization program (Oligo 4.1, National Biosciences, Plymouth, MN) and were based on the GeneBank accession number [17] for the appropriate mouse mRNA sequence. Thermocycler settings were $94^{\circ} \mathrm{C}$ for $15 \mathrm{~s}, 55^{\circ} \mathrm{C}$ for $15 \mathrm{~s}$, and $72^{\circ} \mathrm{C}$ for $1 \mathrm{~min}$ for each primer pair. To ensure that the DNA product was examined at the exponential portion of the PCR curve, the following number of cycles was used for each mRNA: 26 cycles for Fas, Fas-L, Bad, Bax and Bcl-xl; 35 cycles for bak, Bcl-xs, Bid, Bcl-w, Bak and Bcl-2. $\beta$-actin expression (equal number of PCR cycles to the respective transporter gene) was also generated for each sample as a control. The PCR products were applied to a $2 \%$ agarose gel for $1 \mathrm{~h}$ at 160 volts. PCR products were imaged, and results are expressed relative to the expression of $\beta$ actin.

\section{Statistical analysis}

Results are expressed as the mean $\pm \mathrm{SD}$. Data analysis was performed using unpaired $t$-tests and one-way analysis of variance, with $p<0.05$ considered significant. Post-hoc intergroup analysis was performed using Bonferroni $t$-tests.

\section{Results}

Physiologic changes in the mouse

The TPN + L group had a lower 7-day survival rate $(71 \%)$ compared with the control group $(100 \%)$ and the TPN-L group $(83 \%)$. Liver wet weight was the same in both TPN groups $(0.8 \pm 0.1 \mathrm{~g})$ and was significantly decreased compared with the control group $(1.3 \pm 0.2 \mathrm{~g}$; $p<0.05)$. Serum biochemical parameters are shown in Table 1. In the TPN + L group, AST levels $(640 \pm 252 \mathrm{U} /$ $\mathrm{L}, p<0.05)$ were increased significantly compared with controls $(139 \pm 50 \mathrm{U} / \mathrm{L})$ and TPN-L groups $(130 \pm 54 \mathrm{U} /$ $\mathrm{L} ; p<0.05)$. Other laboratory values of note consisted of an elevated glucose level in the TPN-L group but normal cholesterol and G-GTP levels in all groups (Table 1).

\section{Hepatocyte apoptosis}

Hepatocyte apoptosis, expressed as a ratio of positive cells per 200 hepatocytes using TUNEL staining, was relatively infrequent in all histologic specimens. How- 
Table 1 Serum biochemical parameters from mice in each treatment group ( $A S T$ aspartate aminotransferase, $A L T$ alanine aminotransferase, Alk phos alkaline phosphatase, G-GTP gammaguanosine 5'-triphosphate)

\begin{tabular}{llll}
\hline Parameter & Control & TPN + Lipids & TPN-Lipids \\
\hline AST (U/1) & $139 \pm 50$ & $640 \pm 252^{\mathrm{a}}$ & $130 \pm 54$ \\
ALT(U/1) & $51 \pm 12$ & $74 \pm 21$ & $73 \pm 26$ \\
Alk phos(U/l) & $28 \pm 12$ & $27 \pm 13$ & $39 \pm 20$ \\
G-GTP(U/l) & $17 \pm 5$ & $22 \pm 8$ & $12 \pm 4$ \\
Glucose & $143 \pm 47$ & $125 \pm 30$ & $140 \pm 50$ \\
Cholesterol (mg/dl) & $66 \pm 14$ & $80 \pm 28$ & $78 \pm 12$
\end{tabular}

${ }^{\mathrm{a}} p<0.05$

ever, there was a significant and almost two-fold increase in hepatocyte apoptosis in the $\mathrm{TPN}+\mathrm{L}$ group $(0.56 \pm 0.03)$ compared with both control $(0.24 \pm 0.06)$ and TPN-L groups $(0.35 \pm 0.07 ; p<0.05)$ (Fig. 1).

To help identify the potential mechanisms involved in the development of this increased hepatocyte apoptosis, we then examined the expression of a number of factors responsible for mediating hepatocyte apoptosis.

mRNA expression of Fas/ Fas-L mRNA expression

Fas mRNA expression significantly increased 1.5 times in the TPN + L group $(2.30 \pm 0.27, p<0.05)$ compared with the control $(1.75 \pm 0.11)$ and TPN-L groups $(1.52 \pm 0.16)$. Fas-L mRNA expression was not significantly different among any of the groups studied (Fig. 2).

mRNA expression of pro-apoptotic factors of the Bcl-2 protein family

The expression of the pro-apoptotic factor Bid significantly decreased in both TPN groups (TPN-L,

Fig. 1a-b Hepatocyte apoptosis by TUNEL staining, expressed as the number of positive cells per 200 hepatocytes, increased in the TPN + L. a Representative histologic sections from the three experimental groups. Note the dark cells representing apoptotic hepatocytes (arrows). Also note that in this figure there are no apoptotic cells in the control group. b Graphic display of the results of TUNEL staining. Results are given as the mean \pm SD
$0.37 \pm 0.15 ; \mathrm{TPN}+\mathrm{L}, 0.46 \pm 0.20)$ compared with the control group $(0.71 \pm 0.29 ; p<0.05)$ (Table 2, Fig. 2). The expression of the pro-apoptotic factor Bcl-xs also significantly decreased in both TPN groups (TPN-L, $0.74 \pm 0.22 ; \mathrm{TPN}+\mathrm{L}, 0.77 \pm 0.11)$ compared with the control group $(1.18 \pm 0.40 ; p<0.05)$. In contrast, the pro-apoptotic factor Bad significantly increased in the TPN $+\mathrm{L}$ group $(0.79 \pm 0.24)$ compared with both the control $(0.16 \pm 0.06)$ and the TPN-L groups $(0.22 \pm 0.05$; $p<0.05)$.

mRNA expression of anti-apoptotic factors of the Bcl-2 protein family

The expression of the anti-apoptotic factor Bcl-xl significantly increased in the TPN $+\mathrm{L}$ group $(0.46 \pm 0.08)$ compared with both the control group $(0.26 \pm 0.08)$ and the TPN-L group $(0.29 \pm 0.04 ; p<0.05)$. Bcl-w expression did not change following treatment in any of the groups. Although Bcl-2 is typically a strong anti-apoptotic factor, it is not normally expressed in hepatocytes, and we did not detect appreciable levels in our experiments (Fig. 3).

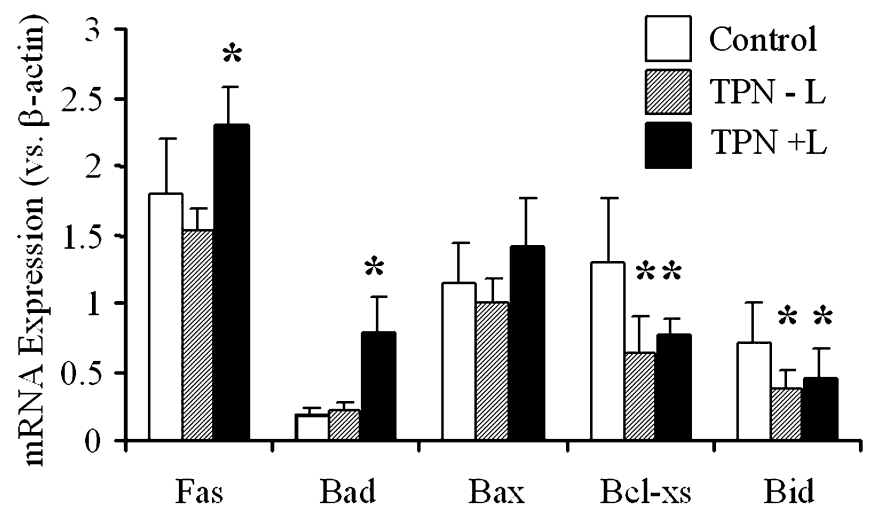

Fig. 2 mRNA expression of pro-apoptotic factors of the Bcl-2 protein family. The expression of the pro-apoptotic factors Bid and Bcl-xs significantly decreased in both TPN groups, and Bad increased in the TPN $+\mathrm{L}$ group. ${ }^{*} p<.05$

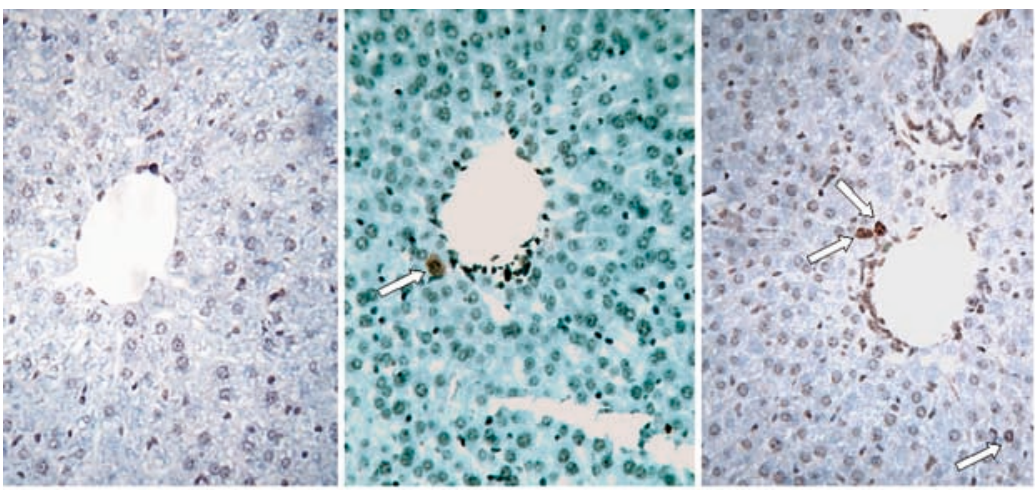

A Control
TPN - L
$\mathrm{TPN}+\mathrm{L}$

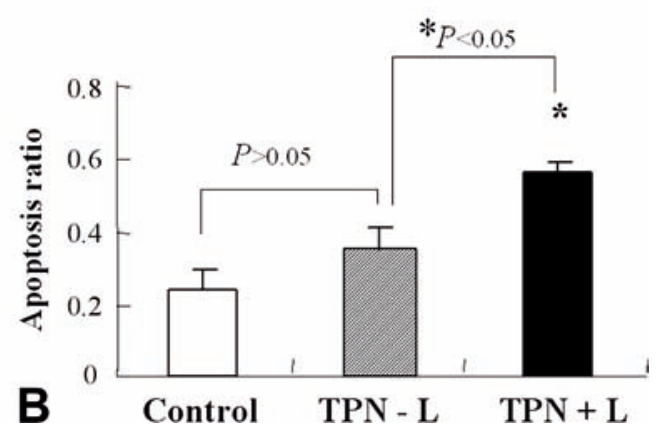


Table 2 mRNA expression of pro- and anti-apoptotic factors of the Bcl-2 protein family (data presented as mean \pm SD). Results of hepatocyte apoptosis (see Fig. 1) as expressed as the number of apoptotic hepatocytes per 200 cells is shown in the final column for comparison

\begin{tabular}{|c|c|c|c|c|c|c|c|}
\hline Group & Bid & Bcl-xs & Bax & Bcl-w & $\mathrm{Bad}$ & Bcl-xl & Apoptosis \\
\hline Control & $0.71 \pm 0.29$ & $1.18 \pm 0.40$ & $1.13 \pm 0.29$ & $0.57 \pm 0.19$ & $0.16 \pm 0.06$ & $0.26 \pm 0.08$ & $2.4 \pm 0.6$ \\
\hline TPN-L & $0.37 \pm 0.15^{\mathrm{a}}$ & $0.74 \pm 0.22^{\mathrm{a}}$ & $0.99 \pm 0.17$ & $0.42 \pm 0.21$ & $0.22 \pm 0.05$ & $0.29 \pm 0.04$ & $3.5 \pm 0.7$ \\
\hline
\end{tabular}

${ }^{\mathrm{a}}$ Compared with control group,

b compared with TPN-L group; $p<0.05$, using ANOVA with post-hoc analysis between groups

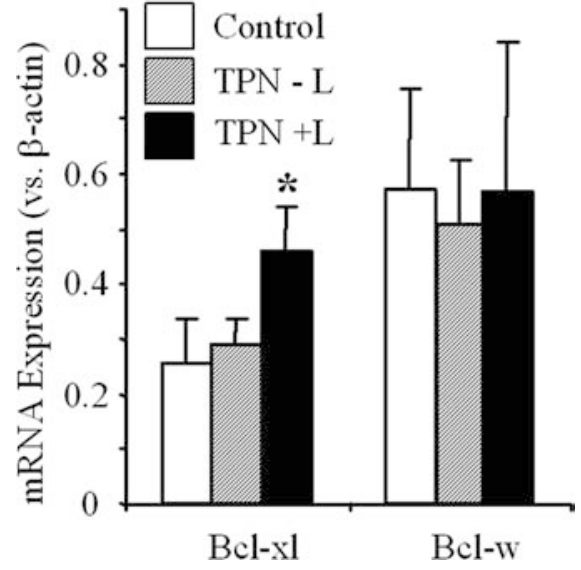

Fig. 3 mRNA expression of anti-apoptotic factors of the Bcl-2 protein family. The anti-apoptotic factor Bcl-xl significantly increased in the TPN $+\mathrm{L}$ group. ${ }^{*} p<.05$

\section{Discussion}

It is known that lipid emulsions suppress the chemotactic function of monocytes in the presence of severe sepsis. Thus, the infusion of fat emulsions may lead to a further deterioration of immunologic function in septic individuals or in those at risk for infection $[19,20]$. In our study, the TPN + L group had a lower 7-day survival rate compared with the survival rates of the control and TPN-L groups. Recently, lipid emulsions have been shown to be causative factors in mitochondrial oxidative stress as manifested by increased rates of apoptosis [12, 13, 14, 15, 16]. Morphological liver examination in our $\mathrm{TPN}+\mathrm{L}$ models demonstrated increased apoptosis. A major intracellular signaling pathway for apoptosis is known to be mediated by the Bcl-2 family of proteins. Pro-apoptotic proteins of the Bcl-2 family act on mitochondria and facilitate the release of cytochrome c [12, $13,15,21]$. In our models, the expression of Bid significantly decreased in both TPN groups in spite of increased Fas expression. Fas stimulation results in normal activation of caspase-3, which has been reported to be arrested in Bid-deficient mice [22]. Esposti et al. suggest that some pro-apoptotic proteins including Bid have an intrinsic capacity of binding and exchanging lipids and lysolipids with mitochondrial membranes [22]. Administration of TPN with lipids might lead to disruption of the signal in normal liver tissue, causing a dysfunction in the lipid exchange within mitochondrial membranes. Our TPN models may have inactivated Bid signals, resulting in non-stimulation of the Fas-caspase pathway. The mitochondrial signal pathway is known to closely correlate with cell cycle arrest, cell apoptosis, and/or cell death. We have previously reported that administration of TPN with lipids results in an arrest of the hepatocyte cell cycle (unpublished data). While the serum lipid pattern of livers exposed to TPN with lipids is normal, the phospholipid fraction contains an abnormal fatty acid pattern consistent with the development of essential fatty acid deficiency [23]. The exact physiologic significance of this is unknown, but it is tempting to speculate that changes in integrity of the hepatic cell membrane as a result of this abnormal fatty acid pattern might account for some of the clinical abnormalities of hepatic function seen during TPN administration [23]. The pro-apoptotic factor (Bad) and anti-apoptotic factor (Bcl-xl) were significantly increased in the TPN $+\mathrm{L}$ group. The activation of Bad has been reported to promote the suppression of anti-apoptotic signals by binding to $\mathrm{Bcl}-\mathrm{xl}$ or Bcl-2. It is known that the role of $\mathrm{Bcl}-\mathrm{xl}$ is that of an anti-inflammatory mediator in macrophages and immature CD4+CD8 + thymocytes $[24,25]$. In our model, the Bcl-xl expression might correlate with increasing macrophage activity after the administration of lipids in TPN models, because the lipid emulsion is known to lead to the suppression of immunologic function $[1,2,3,4,5]$. Further investigation of this problem is warranted. In addition to the lipids themselves, other contaminating factors could also play an essential role. The potential etiology of these changes may also be due to the associated phytosterols that are present in most commercial lipids and that have been suggested to contribute to the development of TPN-associated cholestasis [18].

In conclusion, TPN, both with and without lipids, suppressed the pro-apoptotic signals Bid and Bcl-xs in a mouse model. TPN administration might lead to liver dysfunction by interrupting such cell signal pathways. TPN with lipids activated Fas, the pro-apoptotic factor $\mathrm{Bad}$, and the anti-apoptotic factor Bcl-xl, and induced histological apoptosis. These changes may also contribute to TPN-induced hepatocyte injury (apoptosis) or suppress the ability of liver hepatocytes to regenerate. We hope that future work will direct the use of safer 
TPN solutions that will have fewer deleterious effects on hepatocytes.

\section{References}

1. Barr LH, Dunn GD, Brennan MF (1981) Essential fatty acid deficiency during total parenteral nutrition. Ann Surg 193:304311

2. Benner JW, Coran AG, Weintraub WH, Wesley JR( 1979) The importance of different calorie sources in the intravenous nutrition of infants and children. Surgery 86:429-433

3. Connors RH, Coran AG, Wesley JR (1980) Pediatric TPN: efficacy and toxicity of a new fat emulsion. JPEN J Parenter Enteral Nutr 4:384-386

4. Coran AG, Drongowski R, Sarahan TM, Wesley JR (1982) Studies on the efficacy of a new $20 \%$ fat emulsion in pediatric parenteral nutrition. JPEN J Parenter Enteral Nutr 6:222-225

5. Tashiro T, Mashima Y, Okui K (1983) Effect of fat emulsion (intralipid) on essential fatty acid deficiency during total parenteral nutrition in pediatric patients. Part 2. Clinical study. Nippon Geka Gakkai Zasshi 84:369-378

6. Lata J, Dastych M, Jr., Senkyrik M, et al. (2001) Protective effect of essential phospholipids on liver injury due to total parenteral nutrition. Vnitr Lek 47:599-603

7. La Scala GC, Le Coultre C, Roche BG, et al. (1993) The addition of lipids increases the total parenteral nutrition-associated cholestasis in the rat. Eur J Pediatr Surg 3:224-227

8. Nussbaum MS, Li S, Bower RH, et al. (1992) Addition of lipid to total parenteral nutrition prevents hepatic steatosis in rats by lowering the portal venous insulin/glucagon ratio. JPEN J Parenter Enteral Nutr 16:106-109

9. Nakagawa M, Hiramatsu Y, Mitsuyoshi K, et al. (1991) Effect of various lipid emulsions on total parenteral nutrition-induced hepatosteatosis in rats. JPEN J Parenter Enteral Nutr 15:137143

10. Ikuta K, Mishina Y, Nimura Y, et al. (1995) Effect of lipid emulsions for total parenteral nutrition on regeneration of the liver after partial hepatectomy in rats. Nutrition 11:365-370

11. Aksnes J, Borsum K, Rollag H, Hovig T (1996) Intravascular lung macrophages play an essential role in lipid entrapment and the inflammatory tissue reaction seen after long-term lipidbased parenteral nutrition in pigs. An ultrastructural study. APMIS 104:429-436

12. Zhao Y, Li S, Childs EE, et al. (2001) Activation of pro-death Bcl-2 family proteins and mitochondria apoptosis pathway in tumor necrosis factor-alpha-induced liver injury. J Biol Chem 276:27432-27440

13. Lutter M, Perkins GA, Wang X (2001) The pro-apoptotic Bcl-2 family member tBid localizes to mitochondrial contact sites. BMC Cell Biol 2:22

14. Roucou X, Montessuit S, Antonsson B, Martinou JC (2002) Bax oligomerization in mitochondrial membranes requires tBid (caspase-8-cleaved Bid) and a mitochondrial protein. Biochem J 368:915-921

15. Esposti MD, Erler JT, Hickman JA, Dive C (2001) Bid, a widely expressed proapoptotic protein of the Bcl-2 family, displays lipid transfer activity. Mol Cell Biol 21:7268-7276

16. Werner AB, de Vries E, Tait SW, et al. (2002) Bcl-2 family member Bfl-1/A1 sequesters truncated bid to inhibit is collaboration with pro-apoptotic Bak or Bax. J Biol Chem 277:22781-22788

17. Wildhaber BE, Lynn KN, Yang H, Teitelbaum DH (2002) Total parenteral nutrition-induced apoptosis in mouse intestinal epithelium: regulation by the $\mathrm{Bcl}-2$ protein family. Pediatr Surg Int 18:570-575

18. Iyer K, Spitz L, Clayton P (1999) New insight into mechanisms of parenteral nutrition-associated cholestasis: role of plant sterols. J Pediatr Surg 33:1-6

19. Chen WJ, Mo ST, Yu LJ, Chen KM (1987) Effects of exogenous fat emulsion on lymphocyte function in septic rats. Zhonghua Min Guo Wei Sheng Wu Ji Mian Yi Xue Za Zhi 20:198-203

20. Chen WJ, Yu LJ, Mo ST, et al. (1986) Effects of exogenous fat emulsion (Intralipid) on chemotactic function of monocytes and polymorphonuclear cells in sepsis. Zhonghua Min Guo Wei Sheng Wu Ji Mian Yi Xue Za Zhi 19:104-111

21. Lieser MJ, Park J, Natori S, et al. (1998) Cholestasis confers resistance to the rat liver mitochondrial permeability transition. Gastroenterology 115:693-701

22. Degli Esposti M (2002) Sequence and functional similarities between pro-apoptotic Bid and plant lipid transfer proteins. Biochim Biophys Acta 1553:331-340

23. Pulito AR, Santulli TV, Wigger HJ, et al. (1976) Effects of total parenteral nutrition and semi-starvation on the liver of beagle puppies. J Pediatr Surg 11:655-663.

24. Lakics V, Medvedev AE, Okada S, Vogel SN (2000) Inhibition of LPS-induced cytokines by Bcl-xL in a murine macrophage cell line. J Immunol 165:2729-2737

25. Grillot DA, Merino R, Nunez G (1995) Bcl-XL displays restricted distribution during $\mathrm{T}$ cell development and inhibits multiple forms of apoptosis but not clonal deletion in transgenic mice. J Exp Med 182:1973-1983 